Gut, 1960, 1, 111.

\title{
A TEST OF PANCREATIC FUNCTION IN MAN BASED ON THE ANALYSIS OF DUODENAL CONTENTS AFTER ADMINISTRATION OF SECRETIN AND PANCREOZYMIN
}

BY

\author{
P. BURTON, D. G. EVANS*, A. A. HARPER, HENRY T. HOWAT, S. OLEESKY, \\ J. E. SCOTT, and H. VARLEY
}

\section{From a Medical Unit and the Clinical Laboratory, Manchester Royal Infirmary, and the Department of Physiology, Medical School, King's College, Newcastle upon Tyne}

Pancreozymin in man as in animals appears to act as a specific enzyme stimulant. The preparations of pancreozymin used in these experiments also contain cholecystokinin, which causes the gall bladder to contract, and a smooth muscle stimulant, possibly substance $\mathrm{P}$.

The duodenal contents obtained in response to a standard dose of secretin and pancreozymin have been collected quantitatively in man and the volume and amount of bicarbonate, amylase, trypsin, and lipase measured in order to study pancreatic function. The results of 105 tests undertaken on a normal group, in pancreatic and biliary disease, and in non-pancreatic steatorrhoea have been analysed.

In localized pancreatic lesions and after recovery from acute pancreatitis, normal function is often retained. Mild functional impairment may be demonstrated only by a poor enzyme output in the post-pancreozymin fractions, while at a later stage bicarbonate output is affected and finally the volume of the duodenal contents is reduced. The secretin-pancreozymin test is most valuable, therefore, in the more chronic and advanced forms of pancreatic disease in which it gives a good assessment of residual pancreatic function. In diagnosis care must be taken in interpreting a functional test in terms of anatomical pathology. The test has proved useful not only in diagnosis but also as a guide to treatment and an index of prognosis.

In 1902, Bayliss and Starling showed that extracts of duodenal mucosa contained a material, secretin, which on intravenous injection caused the pancreas to secrete. The earliest attempts to establish a test of pancreatic function in man by stimulating the pancreas with secretin were made in Chiray's clinic in Paris (Chiray, Salmon, and Mercier, 1926; Chiray, Jeandel, and Salmon, 1930; Bolgert, 1935). Voegtlin, Greengard, and Ivy (1934) in America and Voet (1943) in Belgium conducted similar experiments. It was not until Ågren and Lagerlöf (1936), who used a purified preparation of secretin, adopted the double lumen tube method of Lim, Matheson, and Schlapp (1923) to obtain uncontaminated specimens of duodenal juice that accurate quantitative measurements of pancreatic function could be made. Since that time the technique elaborated by Ågren and Lagerlöf has been closely followed by other workers and the value of

*Present address: Department of Biological Standards, National Institute of Medical Research, Mill Hill, London. the secretin test in assessing pancreatic function in man confirmed (Lagerlöf, 1939, 1942; Diamond, Siegel, Gall, and Karlen, 1939; Diamond and Siegel, 1940, 1941; Comfort and Osterberg, 1940; Pratt, Brugsch, and Rostler, 1940; Pollard, Miller, and Brewer, 1942; Lake, 1947; Dornberger, Comfort, Wollaeger, and Power, 1948; Dreiling and Hollander, 1948, 1950; Friedman and Snape, 1950; Dreiling, 1950, 1951, 1953, 1955; Dreiling and Janowitz, 1957; Wenger and Raskin, 1958).

In anaesthetized animals secretin produced a large volume of pancreatic juice of constant alkalinity and low enzyme content. Harper and Raper (1943) isolated from the small intestine a second material, other than secretin, which increased the enzyme output by the pancreas without affecting the volume of juice. This material they named pancreozymin. Crick, Harper, and Raper (1949) later published a revised method of preparing secretin and pancreozymin and preliminary experiments showed that pancreozymin had the same effect on man as in animals (Duncan, Harper, Howat, 
Oleesky, and Varley, 1950; Howat, 1952). In the present paper the effects produced by secretin and pancreozymin on the volume and composition of the duodenal contents in normal adults is described and compared with those in patients who have pancreatic disease.

When this work was started pancreozymin preparations were found to contain cholecystokinin (Ivy and Oldberg, 1928), which causes a contraction of the gall bladder in animals and man (Duncan, Evans, Harper, Howat, Oleesky, Scott, and Varley, 1953). A test of gall bladder function in man has been based on this property of the extracts (Duncan et al., 1952; Burton, Harper, Howat, Scott, and Varley, 1960a).

\section{Methods}

SeCretin and Pancreozymin.-These were prepared from pig intestine according to the method of Crick et al. (1949). Aqueous solutions of secretin $(2.5 \mathrm{mg} . / \mathrm{ml}$.) and of pancreozymin $(7 \mathrm{mg}$. $/ \mathrm{ml}$.) were sterilized by filtration through a "gradocol" membrane. The sterile solutions were then freeze-dried in ampoules. In this state both are pale yellow powders soluble in water. Stored in the dark at $4^{\circ} \mathrm{C}$. they showed no appreciable loss of potency over two years.* Neither secretin nor pancreozymin produced any anaphylactic reactions in guinea-pigs, and no toxic effects were observed in mice following intravenous injections of secretin and pancreozymin in doses per kilogram/body weight up to 200 times those given to patients.

Varying amounts of secretin and pancreozymin, up to 2.5 units of both, have been given to 285 adult subjects, secretin alone to 16 , and pancreozymin alone to 10 . In most cases the dosage employed for both secretin and pancreozymin has been 1.7 units per kilogram of body weight. Immediately before use the extract is dissolved in pyrogen-free distilled water. Both preparations are given intravenously. The injection of secretin in $10 \mathrm{ml}$. of water can be completed within two minutes. After only two of 301 secretin injections $(0.7 \%)$ has any untoward effect been noted. After pancreozymin, however, in a total of 295 injections, general symptoms have been experienced by 38 patients $(13 \%)$. In only nine $(3 \%)$ were reactions of even moderate severity encountered; in the others they were negligible and the subjects complained only on being questioned. The minor sensations were variously described as a flushing of the face, a hot head, clammy skin, nausea or sickliness, a sinking feeling in the upper abdomen. In the nine more severe instances the patients complained of faintness which was associated with slowing of the pulse. Reactions were of such severity as to warrant discontinuing the infusion on three occasions $(1 \%)$. No allergic reactions were encountered but these biological preparations have not been given to asthmatic subjects. In a few instances patients complained of abdominal discomfort which

* Much of the secretin and pancreozymin used in this study has been provided by Boots Pure Drug Company, Limited, Nottingham. resembled a bowel pain rather than a pain arising in the pancreas or gall bladder. One man, aged 59, who had a large incisional hernia of the abdomen and a large scrotal hernia, complained during the injection that his testicles were moving. Intense small bowel motor activity was observed for some 10 minutes in the hernial sacs. These effects on the vasomotor system and intestinal muscle are not caused by histamine or 5-hydroxytryptamine. They may be due to the presence in pancreozymin preparations of the vasodilator and plain muscle stimulant, substance $P$, which Euler and Gaddum (1931) have found in intestinal extracts. Jorpes and Mutt have recently succeeded in separating this material from the pancreozymin and cholecystokinin fractions of pancreczymin preparations (Hultman, $1955 \mathrm{a}$ and b; Jorpes and Mutt, 1956, 1959).

In addition local pain in the arm at the site of injection or referred along the course of the vein was experienced by 16 patients ( $6 \%$ of the total). This was attributed to venous spasm. Thrombosis of a segment of an arm vein was encountered in seven patients $(2.5 \%)$ following secretin and pancreozymin, a complication particularly liable to occur in patients with difficult veins, where recent intravenous fluids have been given, when numerous venepunctures were made and in patients with advanced malignant disease. All the untoward effects are aggravated by the rapid delivery of too concentrated solutions of pancreozymin. Since we adopted the technique of dissolving the required dose of pancreozymin in 16 to $20 \mathrm{ml}$. of distilled water and injecting it slowly in four or five minutes, reactions were reduced by two-thirds and were correspondingly milder. All reactions have been of a transient nature. There has been no suspicion that pancreatitis may have been induced or aggravated by giving either of these preparations.

TeChNiQue of IntUbation.-In place of the two separate tubes, one in the stomach and the other in the duodenum which we used in our early experiments (Howat, 1952), we now pass a single radio-opaque double lumen tube weighted by a thin latex bag containing $1.5 \mathrm{ml}$. of mercury, which has proved less disagreeable to patients.

Two methods of intubation have been used.

(a) Rapid Method.-With the patient seated and inclining slightly forward, the tube is rapidly introduced through the mouth into the stomach to the $60 \mathrm{~cm}$. mark. The patient then lies semi-prone on the right side and with the foot of the couch raised $35 \mathrm{~cm}$., the tube is passed on to the pylorus, being guided and controlled by pressure of the flat hand and fingers on the anterior abdominal wall up towards the right costal margin. Once the distal end of the tube reaches the pylorus the tube is passed to $75 \mathrm{~cm}$. When the tube enters the duodenum (in most instances in 25 to 30 minutes) the patient sits up or walks about. Adequate radioscopic control of this method is necessary at all stages.

(b) Gradual Method.-Late in the previous evening the tube is passed by mouth to the $60 \mathrm{~cm}$. mark but no further. A barbiturate hypnotic is given, the foot of the 
bed is raised, and the patient is encouraged to sleep on the right side. No food is given but water is available until an hour before the test. On waking the tube is advanced to the $75 \mathrm{~cm}$. mark. By morning the tube has entered the duodenum and its location in the alimentary tract is checked radioscopically and adjusted immediately before the test.

During the test the patient reclines on a couch with head and shoulders comfortably raised. Continuous suction at a negative pressure of from 25 to $40 \mathrm{~mm} . \mathrm{Hg}$ is applied to both gastric and duodenal tubes. Salivary ejectors are used throughout the experiment. The technique of Ågren and Lagerlöf is followed, both gastric and duodenal contents being collected in successive 10-minute samples. After at least two control periods of 10 minutes each (specimens $\mathrm{C} 1$ and $\mathrm{C} 2$ ), the secretin is injected. Three 10-minute samples are collected in the next half hour (specimens D1, D2, and D3). Between the twenty-fifth and thirtieth minute after the secretin injection pancreozymin is injected and the aspiration continued for a further 30 minutes (specimens D4, D5, and D6), at the end of which the collection ends. If the volume recovered has been low (less than $150 \mathrm{ml} / 60 \mathrm{~min}$.) or if the flow has been so delayed or capricious as to suggest incomplete aspiration of the duodenal contents, the position of the tube is again verified radioscopically after which the tube is withdrawn. The fractions of gastric and duodenal contents are collected in glass tubes surrounded by ice during the time of collection, and at the end of each 10-minute period the duodenal sample is diluted with an equal volume of glycerol and stored on ice to preserve the enzymes. Samples of blood for estimation of serum enzymes are collected before and at various intervals for 24 hours after giving secretin and pancreozymin. The results of the serum enzyme estimations are described in a paper by Burton, Hammond, Harper, Howat, Scott, and Varley (1960b).

Chemical Methods.-The volume of the duodenal contents is measured. Bicarbonate concentration is estimated by the gasometric method according to Peters and Van Slyke (1932). The concentration of amylase is determined by Lagerlöf's adaptation of the method of Nørby (Lagerlöf, 1942); of trypsin by the method of Gowenlock (1953); and of lipase by the method of Cherry and Crandall (1932). The outputs of bicarbonate and enzymes are obtained from the product of the concentrations and the volume of the samples. The icteric index of Meulengracht is used as a measure of the concentration of bile in the duodenal contents. In comparing the mean results in normal subjects with those in groups of patients the $t$ test has been applied using the normal series only for the estimation of variance (Pearson and Hartley, 1954).

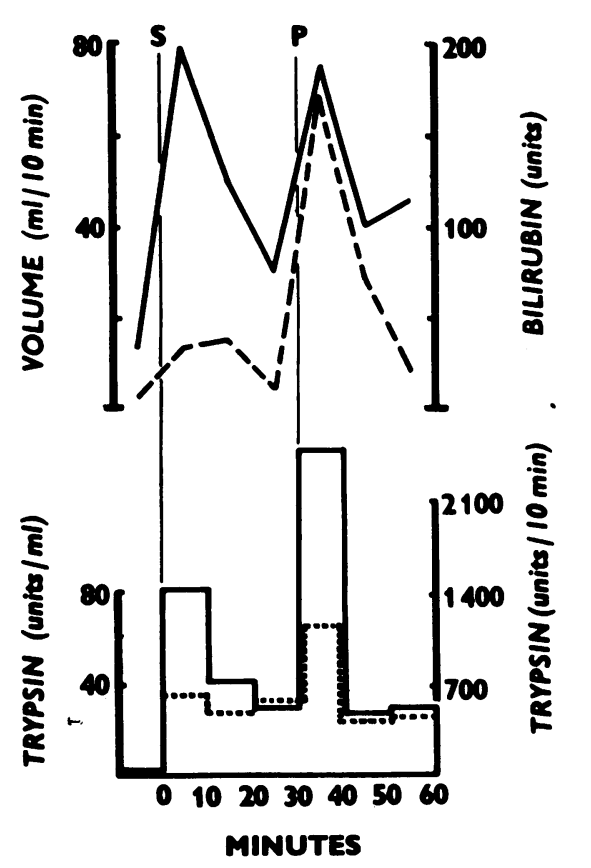

FIG. 1.-The Secretin-pancreozymin Test.-The volume of duodenal contents, concentration of bilirubin, concentration and output of trypsin compared in two normal subjects (on left) in response to secretin $(S)$ followed in 30 min. by pancreozymin $(P)$ and (on right) in response to secretin $(S)$ followed in $30 \mathrm{~min}$. by a second equal injection of secretin $(S)$.

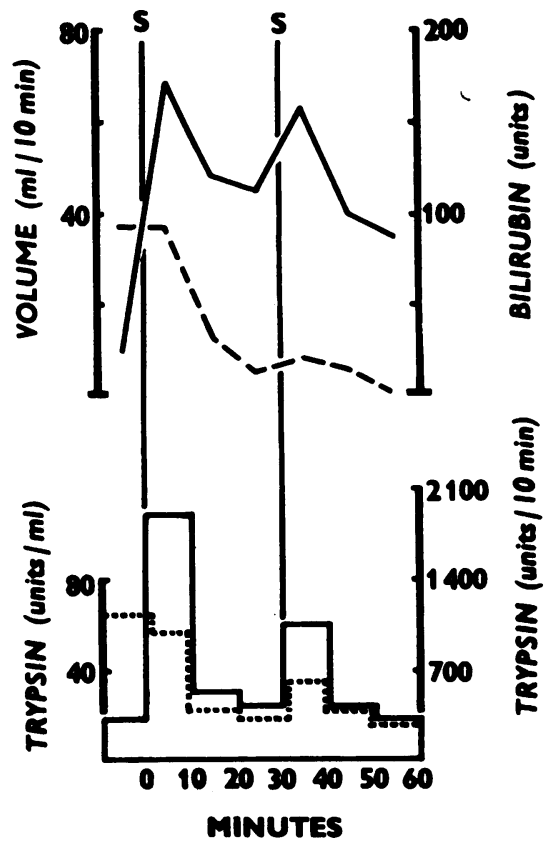

Upper half
- Volume (ml./10 min.)
--- Bilirubin concentration (units)
Lower half
$-\ldots$ Concentration of trypsin
(units/ml.)
Output of trypsin (units/10 min.) 


\section{RESULTS}

Normal Pancreas.-In fasting man, when gastric contents are prevented from entering the duodenum, the volume of duodenal contents recovered in successive 10-minute samples falls to a low level. The fluid usually contains a moderate concentration of bile and only a little bicarbonate. On the other hand the enzymes-amylase, trypsin, and lipase-may be present in considerable concentration.

When secretin is given alone the volume of the duodenal aspirate increases rapidly in the first 10 minutes and then gradually falls over the next 50 minutes. When pancreozymin is given 30 minutes after secretin the output of duodenal contents again increases. This increase is associated with the appearance of gall bladder bile in the fluid and is largely due to the cholecystokinin in pancreozymin extracts causing partial emptying of the gall bladder (Fig. 1).

With the outpouring of fluid after the injection of secretin the concentration of bicarbonate also rises but reaches a maximum more slowly than the volume, usually in the third 10-minute fraction (specimen D3). This sample is frequently colourless showing absence of admixture with bile, and in composition approaches more nearly to pure pancreatic juice than any other sample. There is a

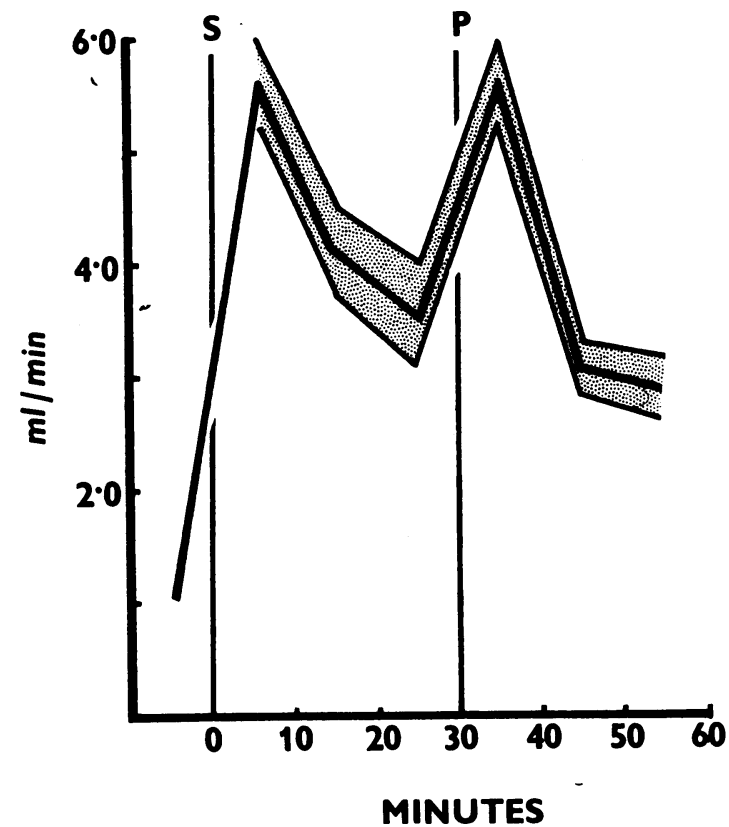

FIG. 2.-The Secretin-pancreozymin Test.-The mean volume of duodenal contents \pm 2 S.E. of mean in 21 normal subjects (ml./min.). fall in the bicarbonate concentration when the gall bladder empties following pancreozymin although the output of bicarbonate in the first specimen after pancreozymin (D4) is increased. In the final samples (D5 and D6) bicarbonate output diminishes as the volume diminishes (Fig. 3).

In healthy man the three pancreatic enzymes are secreted in parallel fashion by the pancreas. The concentration and output of enzymes increase after the administration of secretin (in specimen D1) and then fall to a low level. There is a comparable peak in concentration and output of enzymes in the first post-pancreozymin sample (D4). The rise after secretin is due to an outpouring of enzyme in the first five minutes of the test and is probably due to the washing out of enzymes from the ducts of the resting gland by the flow of secretin-stimulated juice. The increase in output of the enzymes (concentration $\times$ volume) which follows the dosage of pancreozymin given in this test is of the same order of magnitude as that which follows secretin. If a second injection of secretin is substituted for pancreozymin a rise in volume follows due to a further outpouring of pancreatic juice, but the increased output of bile and enzymes, characteristic of the response to pancreozymin preparations, is absent (Fig. 1).

The test was carried out in 21 normal adult

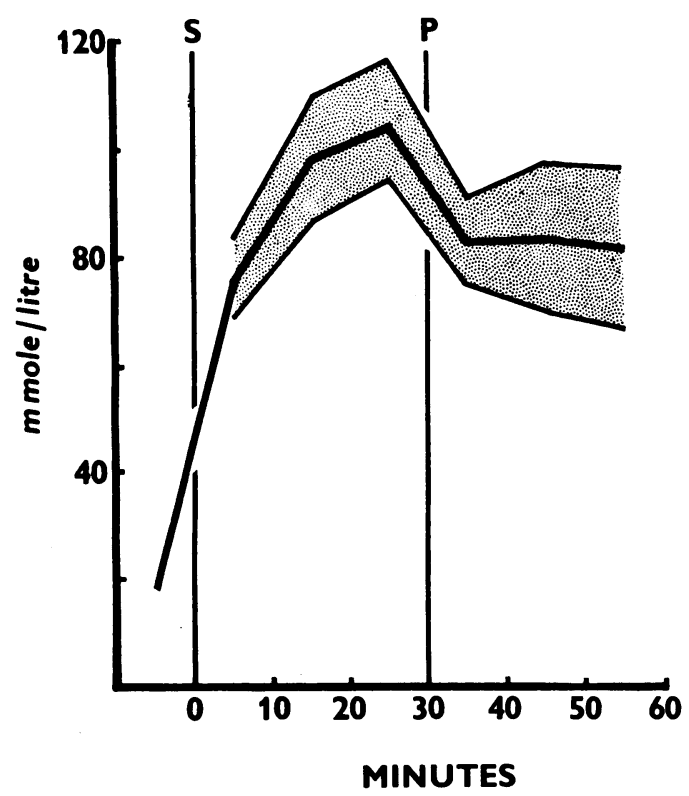

FIG. 3.-The Secretin-pancreozymin Test.-The mean concentration of bicarbonate \pm 2 S.E. of mean in 18 normal subjects (m.mole/litre). 
subjects, a group made up of 16 healthy medical students, aged 21 to 27 years, and five patients aged 35 to 63 years, in whom the liver, gall bladder, and pancreas were known to be normal. The mean volumes and the mean concentration and outputs of bicarbonate, amylase, trypsin, and lipase for this group are shown in Tables I and II and Figs. 2, 3, 4 , and 5. The standard errors of the mean total volume and bicarbonate output are about $5 \%$ of the mean. On the other hand, the standard errors of the mean outputs of amylase, trypsin, and lipase are each about $10 \%$ of the mean, which seems to indicate either a greater variability in the output of these enzymes or an inherently greater error in the methods of estimating enzyme activities than in the method of measuring bicarbonate. The variances of the means of the samples collected immediately after secretin and pancreozymin (samples D1 and D4) have been compared by calculating the variance ratio of these two samples. There was no significant difference between the variances for the volume, bicarbonate output, or lipase output in the samples, but the variance after pancreozymin was significantly less than after secretin for amylase output $(P<0.05)$. and for trypsin output $(P<\mathbf{0 . 0 0 1})$. We interpret this as an indication of the greater variation in the amylase and trypsin content of the dead space in the resting gland which is washed out by secretin

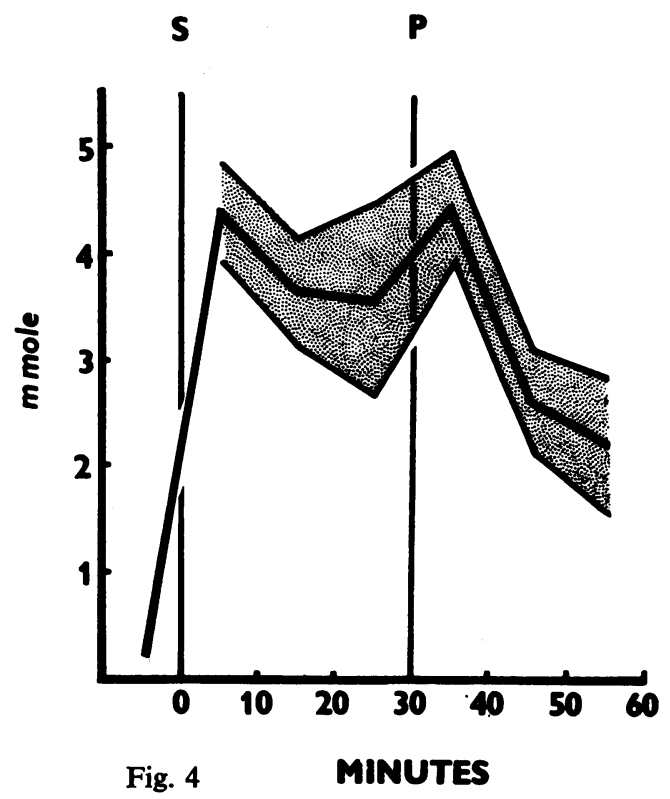

Fig. 4.-The Secretin-pancreozymin Test.-The mean output of bicarbonate \pm 2 S.E. of mean in 18 normal subjects (m.moles).

FIG. 5.-The Secretin-pancreozymin Test.-The mean output of amylase, trypsin, and lipase in 20 normal subjects graphed to show the parallelism of enzyme output.

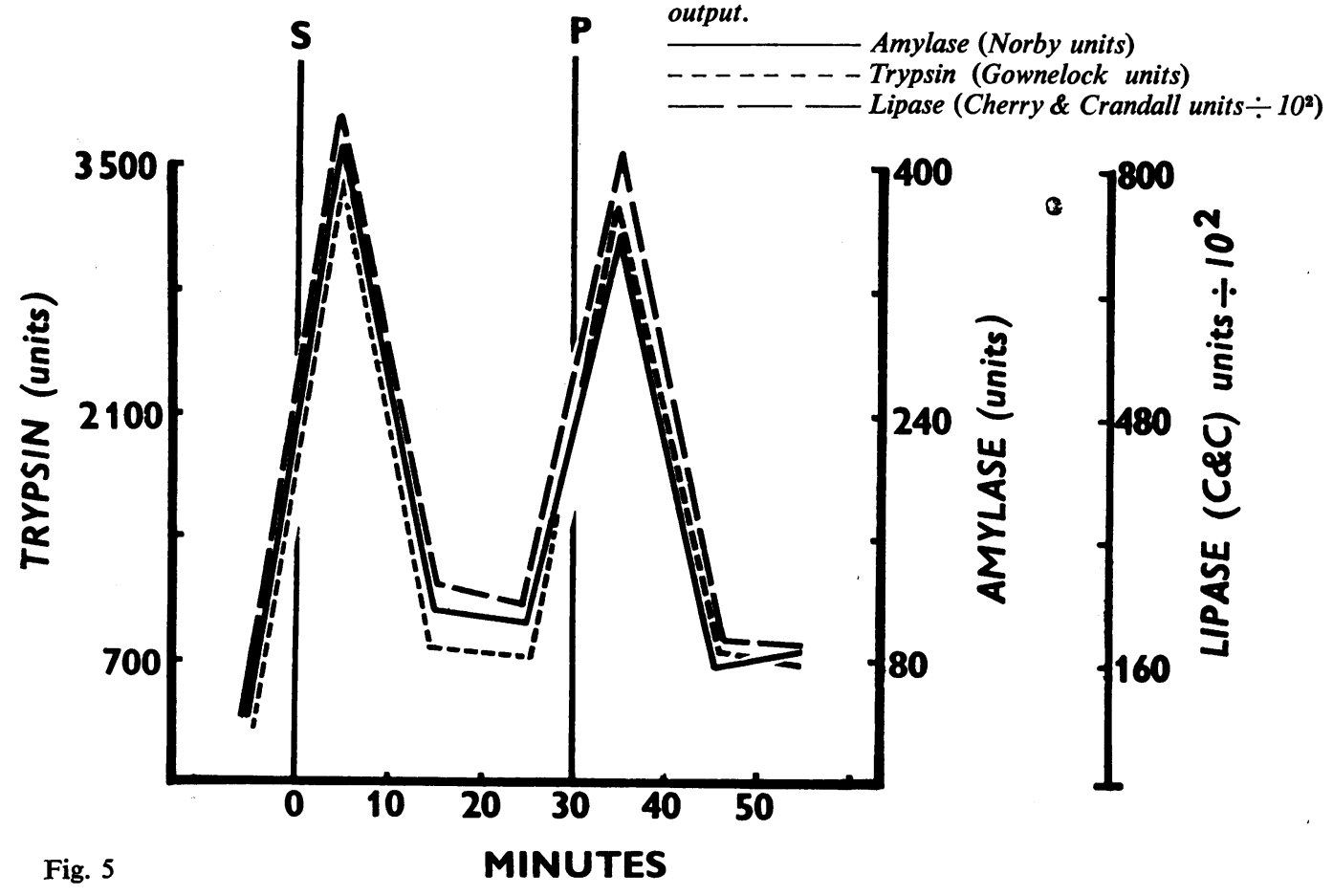


TABLE I

VOLUME AND BICARBONATE AFTER SECRETIN AND PANCREOZYMIN

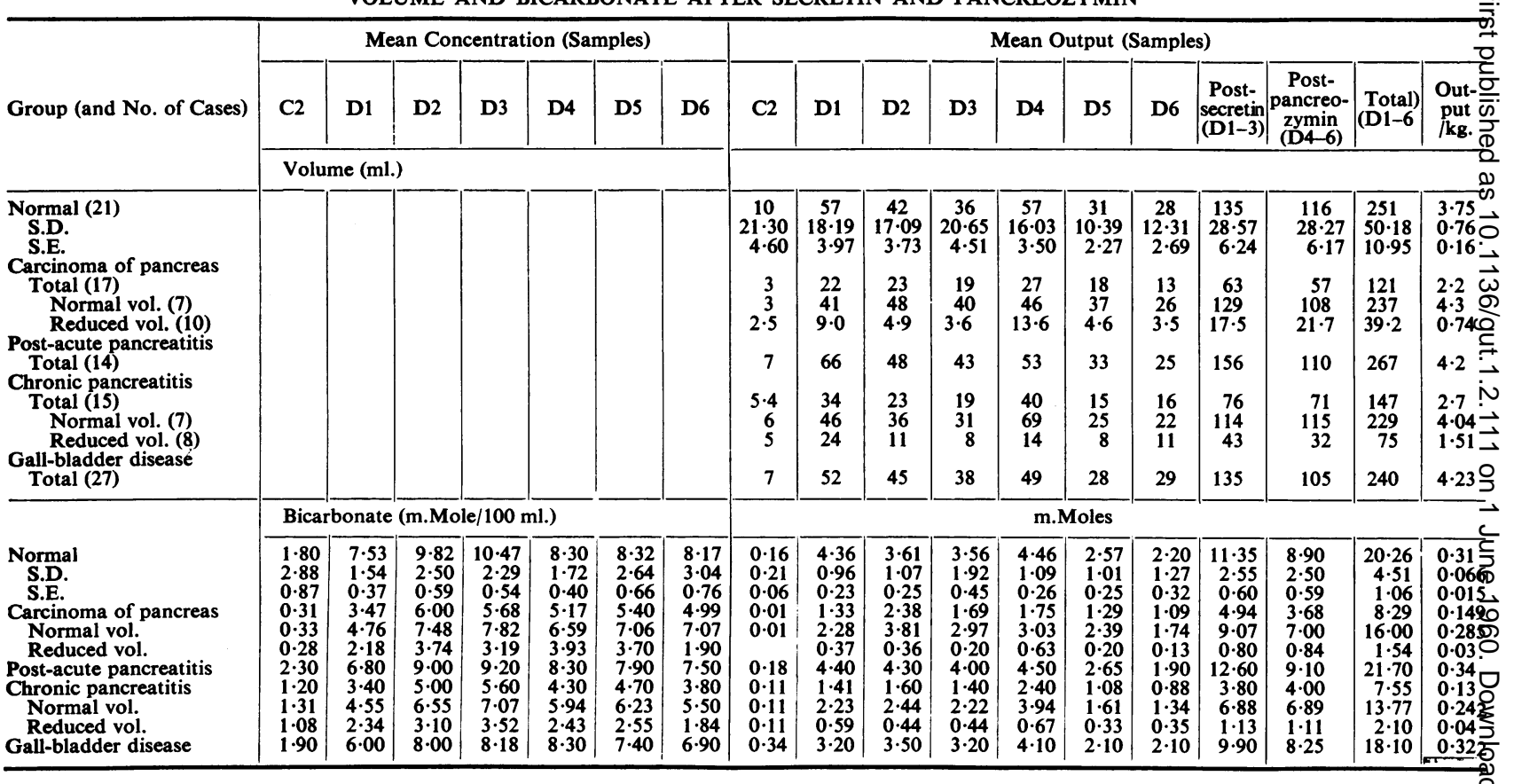

\section{TABLE II}

AMYLASE, TRYPSIN, AND LIPASE AFTER SECRETIN AND PANCREOZYMIN

\begin{tabular}{|c|c|c|c|c|c|c|c|c|c|c|c|c|c|c|c|c|c|c|}
\hline \multirow[b]{2}{*}{ Group } & \multicolumn{7}{|c|}{ Mean Concentration (Samples) } & \multicolumn{11}{|c|}{ Mean Output (Samples) } \\
\hline & C2 & D1 & D2 & D3 & D4 & D5 & D6 & $\mathrm{C} 2$ & D1 & D2 & D3 & D4 & D5 & D6 & $\left|\begin{array}{c}\text { Post- } \\
\text { secretin } \\
\text { (D1-3) }\end{array}\right|$ & \begin{tabular}{|c|} 
Post- \\
pancreo- \\
zymin \\
(D4-6)
\end{tabular} & $\begin{array}{r}\text { Total } \\
(\mathrm{D} 1-6)\end{array}$ & 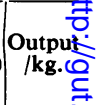 \\
\hline \multirow{3}{*}{$\begin{array}{l}\text { Normal } \\
\text { S.D. } \\
\text { S.E. } \\
\text { Carcinoma of pancreas } \\
\text { Normal vol. } \\
\text { Reduced vol. } \\
\text { Post-acute pancreatitis } \\
\text { Chronic pancreatitis } \\
\text { Normal vol. } \\
\text { Reduced vol. } \\
\text { Gall-bladder disease }\end{array}$} & \multicolumn{7}{|c|}{ Amylase (Nørby units/ml.) } & \multicolumn{11}{|c|}{ Nørby Units } \\
\hline & \begin{tabular}{|r|}
$5 \cdot 66$ \\
$5 \cdot 43$ \\
$1 \cdot 32$ \\
$4 \cdot 74$ \\
$6 \cdot 65$ \\
$2 \cdot 50$ \\
$12 \cdot 36$ \\
3.00 \\
$4 \cdot 45$ \\
0.84 \\
$6 \cdot 50$
\end{tabular} & $\begin{array}{l}7 \cdot 98 \\
4 \cdot 08 \\
0.96 \\
3 \cdot 12 \\
5 \cdot 10 \\
1 \cdot 15 \\
6 \cdot 12 \\
2 \cdot 75 \\
3 \cdot 14 \\
2 \cdot 37 \\
5 \cdot 88\end{array}$ & $\begin{array}{l}2.94 \\
1.69 \\
0.40 \\
1.29 \\
1.81 \\
0.70 \\
2.60 \\
1.87 \\
1.80 \\
1.94 \\
2.65\end{array}$ & $\begin{array}{l}2 \cdot 87 \\
1 \cdot 06 \\
0 \cdot 24 \\
0.90 \\
1 \cdot 28 \\
0 \cdot 52 \\
2 \cdot 50 \\
1 \cdot 84 \\
1 \cdot 59 \\
2 \cdot 13 \\
2.90\end{array}$ & $\begin{array}{l}6.48 \\
3.35 \\
0.75 \\
1.46 \\
2.00 \\
1.00 \\
4.80 \\
2.08 \\
2.45 \\
1.57 \\
4.80\end{array}$ & $\begin{array}{l}2 \cdot 60 \\
1 \cdot 12 \\
0 \cdot 26 \\
1 \cdot 20 \\
1 \cdot 63 \\
0 \cdot 83 \\
3 \cdot 10 \\
1 \cdot 73 \\
2 \cdot 23 \\
1 \cdot 14 \\
2 \cdot 90\end{array}$ & $\begin{array}{l}2.92 \\
1.24 \\
0.28 \\
1.28 \\
1.50 \\
0.97 \\
3.00 \\
1.88 \\
1.84 \\
1.93 \\
2.80\end{array}$ & $\begin{array}{r}42 \\
227 \\
15 \cdot 1 \\
12 \\
12 \\
88 \\
18 \\
24 \cdot 5 \\
9 \\
51\end{array}$ & $\begin{array}{r}411 \\
261 \\
59 \cdot 8 \\
106 \\
184 \\
16 \\
383 \\
95 \\
153 \\
37 \\
280\end{array}$ & $\begin{array}{r}110 \\
68 \\
15 \cdot 7 \\
47 \\
84 \\
4 \\
121 \\
38 \\
64 \\
11 \\
113\end{array}$ & $\begin{array}{r}104 \\
65 \\
14 \cdot 6 \\
28 \\
53 \\
2 \\
111 \\
32 \\
48 \\
14 \\
104\end{array}$ & $\begin{array}{r}358 \\
163 \\
36 \cdot 4 \\
56 \\
103 \\
15 \\
240 \\
102 \\
156 \\
27 \\
219\end{array}$ & $\begin{array}{r}76 \\
42 \\
9 \cdot 3 \\
31 \\
63 \\
3 \\
101 \\
34 \\
57 \\
7 \\
74\end{array}$ & $\begin{array}{r}91 \\
56 \\
12 \cdot 5 \\
27 \\
48 \\
3 \\
73 \\
32 \\
34 \\
29 \\
70\end{array}$ & $\begin{array}{r}624 \\
303 \\
67 \cdot 8 \\
170 \\
321 \\
20 \\
615 \\
162 \\
264 \\
60 \\
497\end{array}$ & $\begin{array}{r}525 \\
197 \\
44 \cdot 0 \\
110 \\
214 \\
20 \\
414 \\
160 \\
247 \\
59 \\
362\end{array}$ & $\begin{array}{r}1,148 \\
453 \\
101 \\
270 \\
535 \\
37 \\
1,029 \\
290 \\
511 \\
97 \\
859\end{array}$ & 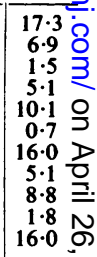 \\
\hline & \multicolumn{7}{|c|}{ Trypsin (Gowenlock units/ml.) } & \multicolumn{11}{|c|}{ Gowenlock Units } \\
\hline \multirow[t]{2}{*}{$\begin{array}{l}\text { Normal } \\
\text { S.D. } \\
\text { S.E. } \\
\text { Carcinoma of pancreas } \\
\text { Normal vol. } \\
\text { Reduced vol. } \\
\text { Post-acute pancreatitis } \\
\text { Chronic pancreatitis } \\
\text { Normal vol. } \\
\text { Reduced vol. } \\
\text { Gall-bladder disease }\end{array}$} & \begin{tabular}{|r|}
41 \\
$31 \cdot 34$ \\
$8 \cdot 69$ \\
47 \\
50 \\
41 \\
58 \\
25 \\
50 \\
11 \\
46 \\
\end{tabular} & \begin{tabular}{r|}
57 \\
$26 \cdot 61$ \\
$6 \cdot 10$ \\
37 \\
46 \\
21 \\
57 \\
27 \\
37 \\
16 \\
47 \\
\end{tabular} & $\begin{array}{r}21 \\
10 \cdot 04 \\
2 \cdot 25 \\
17 \\
20 \\
11 \\
27 \\
17 \\
23 \\
10 \\
23\end{array}$ & $\begin{array}{r}22 \\
8 \cdot 82 \\
1.97 \\
12 \cdot 5 \\
16 \\
8 \\
25 \\
18 \\
24 \\
10 \\
26\end{array}$ & $\begin{array}{r}59 \\
22 \cdot 37 \\
5 \cdot 00 \\
18 \\
25 \\
10 \\
42 \\
25 \\
37 \\
11 \\
41 \cdot 5 \\
\end{array}$ & $\begin{array}{r}25 \\
9 \cdot 72 \\
2 \cdot 17 \\
21 \\
24 \cdot 5 \\
12 \\
30 \\
24 \\
35 \\
9 \\
26\end{array}$ & $\begin{array}{r}22 \\
10 \cdot 54 \\
2 \cdot 36 \\
19 \\
22 \\
10 \\
27 \\
19 \\
28 \\
7 \\
22 \cdot 5\end{array}$ & $\begin{array}{r}332 \\
249 \\
69 \\
156 \\
174 \\
102 \\
529 \\
182 \\
281 \\
107 \\
392\end{array}$ & $\begin{array}{r}3,494 \\
2,180 \\
500 \\
1,343 \\
1,902 \\
365 \\
3,530 \\
1,032 \\
1,786 \\
277 \\
2,490\end{array}$ & $\begin{array}{r}804 \\
517 \\
116 \\
662 \\
970 \\
123 \\
1,259 \\
499 \\
858 \\
80 \\
965\end{array}$ & \begin{tabular}{|r|}
736 \\
414 \\
93 \\
448 \\
739 \\
40 \\
1,089 \\
471 \\
703 \\
146 \\
1,014
\end{tabular} & \begin{tabular}{|r|}
3,259 \\
1,146 \\
256 \\
834 \\
1,412 \\
160 \\
2,256 \\
1,258 \\
2,077 \\
2,303 \\
2,134 \\
\end{tabular} & $\begin{array}{l}798 \\
490 \\
110 \\
648 \\
883 \\
100 \\
906 \\
527 \\
817 \\
121 \\
755\end{array}$ & $\begin{array}{l}675 \\
468 \\
105 \\
483 \\
668 \\
52 \\
618 \\
395 \\
563 \\
158 \\
638\end{array}$ & $\begin{array}{r}5,198 \\
2,743 \\
647 \\
2,492 \\
3,612 \\
534 \\
5,878 \\
1,772 \\
3,347 \\
4,494 \\
4,468\end{array}$ & $\begin{array}{r}4,715 \\
1,583 \\
363 \\
1,990 \\
2,962 \\
289 \\
3,779 \\
2,109 \\
3,457 \\
536 \\
3,501\end{array}$ & $\begin{array}{l}9,884 \\
3,822 \\
927 \\
3,547 \\
6,574 \\
521 \\
9,658 \\
3,600 \\
6,804 \\
796 \\
7,969\end{array}$ & 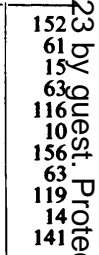 \\
\hline & \multicolumn{7}{|c|}{ Lipase (Cherry \& Crandall units/ml.) } & \multicolumn{11}{|c|}{ Cherry \& Crandall Units $\div 100$} \\
\hline $\begin{array}{l}\text { Normal } \\
\text { S.D. } \\
\text { S.E. } \\
\text { Carcinoma of pancreas } \\
\text { Normal vol. } \\
\text { Reduced vol. } \\
\text { Post-acute pancreatitis } \\
\text { Chronic pancreatitis } \\
\text { Normal vol. } \\
\text { Reduced vo. } \\
\text { Gall-bladder disease }\end{array}$ & $\begin{array}{r}848 \\
680 \\
189 \\
307 \\
516 \\
29 \\
1,108 \\
287 \\
394 \\
206 \\
982\end{array}$ & $\mid \begin{array}{r}1,384 \\
575 \\
136 \\
465 \\
714 \\
116 \\
1,082 \\
469 \\
641 \\
269 \\
1,060\end{array}$ & $\begin{array}{r}658 \\
300 \\
71 \\
282 \\
336 \\
92 \\
492 \\
243 \\
280 \\
191 \\
434\end{array}$ & $\begin{array}{r}671 \\
212 \\
49 \\
181 \\
249 \\
60 \\
388 \\
235 \\
291 \\
137 \\
492\end{array}$ & $\begin{array}{r}1,389 \\
461 \\
106 \\
285 \\
455 \\
86 \\
745 \\
493 \\
603 \\
338 \\
820\end{array}$ & $\begin{array}{r}555 \\
280 \\
64 \\
263 \\
356 \\
46 \\
454 \\
251 \\
369 \\
45 \\
479\end{array}$ & $\begin{array}{r}570 \\
196 \\
45 \\
241 \\
329 \\
86 \\
398 \\
193 \\
259 \\
39 \\
382\end{array}$ & $\begin{array}{r}89 \\
104 \\
29 \\
11 \\
18 \\
2 \\
88 \\
31 \\
36 \\
27 \\
105\end{array}$ & $\begin{array}{l}855 \\
469 \\
110 \\
165 \\
267 \\
22 \\
675 \\
205 \\
333 \\
55 \\
538\end{array}$ & $\begin{array}{r}269 \\
155 \\
37 \\
128 \\
160 \\
15 \\
235 \\
66 \\
106 \\
10 \\
187\end{array}$ & $\begin{array}{r}236 \\
97 \\
22 \\
60 \\
89 \\
10 \\
169 \\
67 \\
101 \\
19 \\
194\end{array}$ & $\begin{array}{r}820 \\
373 \\
86 \\
141 \\
254 \\
9 \\
404 \\
240 \\
349 \\
89 \\
407\end{array}$ & $\begin{array}{r}182 \\
121 \\
28 \\
91 \\
127 \\
6 \\
6 \\
165 \\
65 \\
99 \\
4 \\
157\end{array}$ & $\begin{array}{r}170 \\
102 \\
23 \\
65 \\
100 \\
4 \\
105 \\
35 \\
53 \\
5 \\
5 \\
120\end{array}$ & \begin{tabular}{|r|}
1,321 \\
656 \\
151 \\
331 \\
546 \\
30 \\
1,080 \\
284 \\
540 \\
59 \\
919
\end{tabular} & $\begin{array}{r}1,172 \\
476 \\
109 \\
266 \\
481 \\
15 \\
674 \\
307 \\
501 \\
80 \\
681\end{array}$ & $\begin{array}{r}2,494 \\
1,052 \\
241 \\
571 \\
1,025 \\
40 \\
1,754 \\
549 \\
1,041 \\
119 \\
1,600\end{array}$ & $\begin{array}{c}370 \\
170 \\
40 \\
100 \\
180 \\
0.8 \\
28 \overline{0} \\
9 . \\
18 \% \\
2 \\
28\end{array}$ \\
\hline
\end{tabular}


(which itself does not stimulate enzyme production) compared with the active enzyme secretion after a standard dose of pancreozymin.

Cancer of the Pancreas.-The secretin and pancreozymin test was performed on 17 patients with proved cancer of the pancreas, in 12 of whom the cancer was in the head, two in the body, two diffusely infiltrating the head and body of the pancreas, and one cancer of the ampulla of Vater.

The mean results of these cases are shown in Tables I and II. Characteristic of this group is a reduction in the volume of duodenal contents recovered, due partly to obstruction of the pancreatic ducts and partly to secondary obstruction of the bile ducts when they become involved in growth (Fig. 6). The mean concentration of bicarbonate and enzymes is reduced, the reduction of the concentration of all the enzymes being most marked in the immediate post-pancreozymin fraction (D4). Since the mean output of duodenal contents is so small, the total outputs of bicarbonate and enzymes are all very significantly diminished.

However, in seven of the 17 cases the individual total volumes were not significantly reduced and the mean bicarbonate and enzyme outputs of these

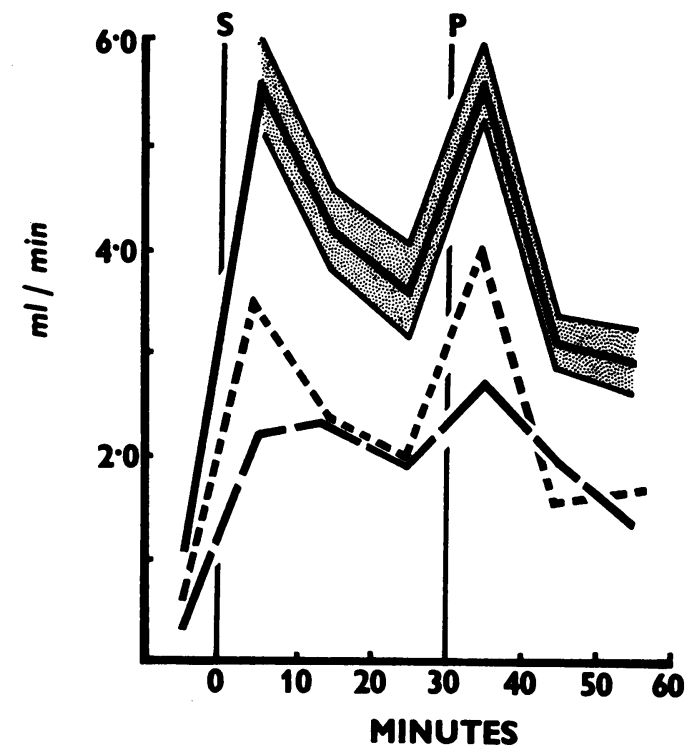

Fig. 6.-The Secretin-pancreozymin Test.- $A$ comparison of the mean volume of duodenal contents (ml./min.) in 21 normal subjects, in 21 patients with cancer of pancreas, and in 15 patients with chronic pancreatitis.
In Figs. Normal \pm 2 S.E. of mean
6,7 Cancer of pancreas
and 8

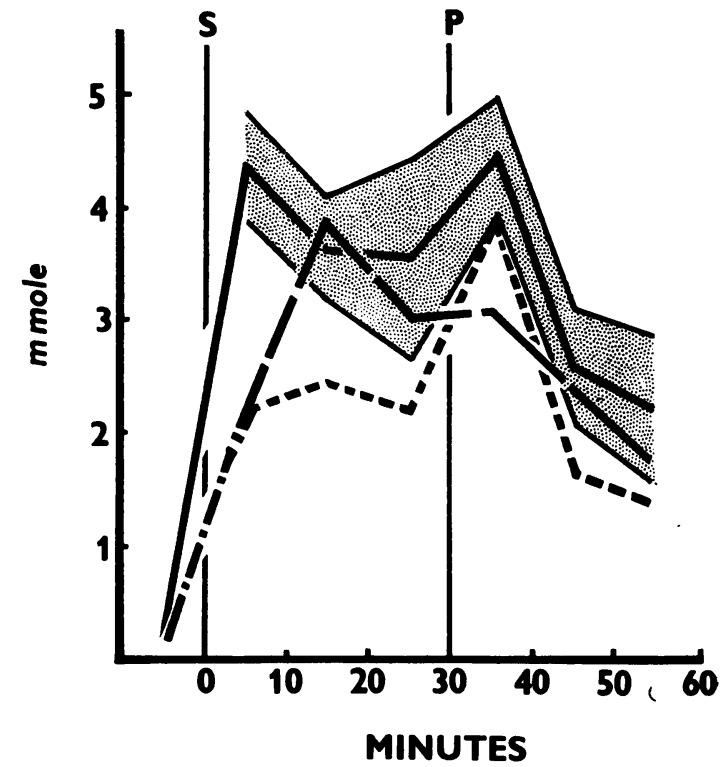

Fig. 7.-The Secretin-pancreozymin Test.-A comparison of the mean output of bicarbonate (m.moles) in 18 normal subjects, in seven patients with cancer of the pancreas but normal volume response, and in seven patients with chronic pancreatitis but normal volume response.

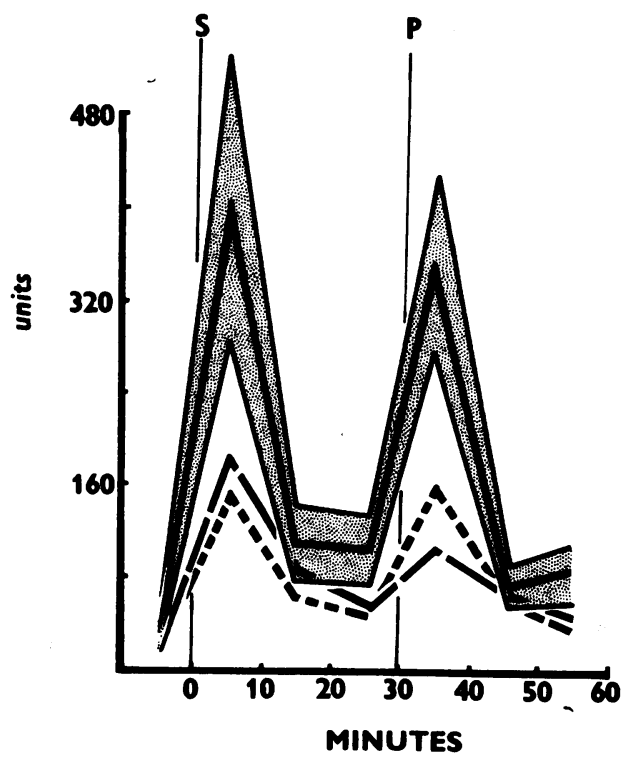

FIG. 8.-The Secretin-pancreozymin Test.-A comparison of the mean amylase output in 20 normal patients, in seven patients with cancer of the pancreas with normal volume response, and in seven patients with chronic pancreatitis but normal response. 
MEANS AND SIGNIFICANCE OF DIFFERENCE BETWEEN MEANS OF NORMAL AND ABNORMAL GROUPS

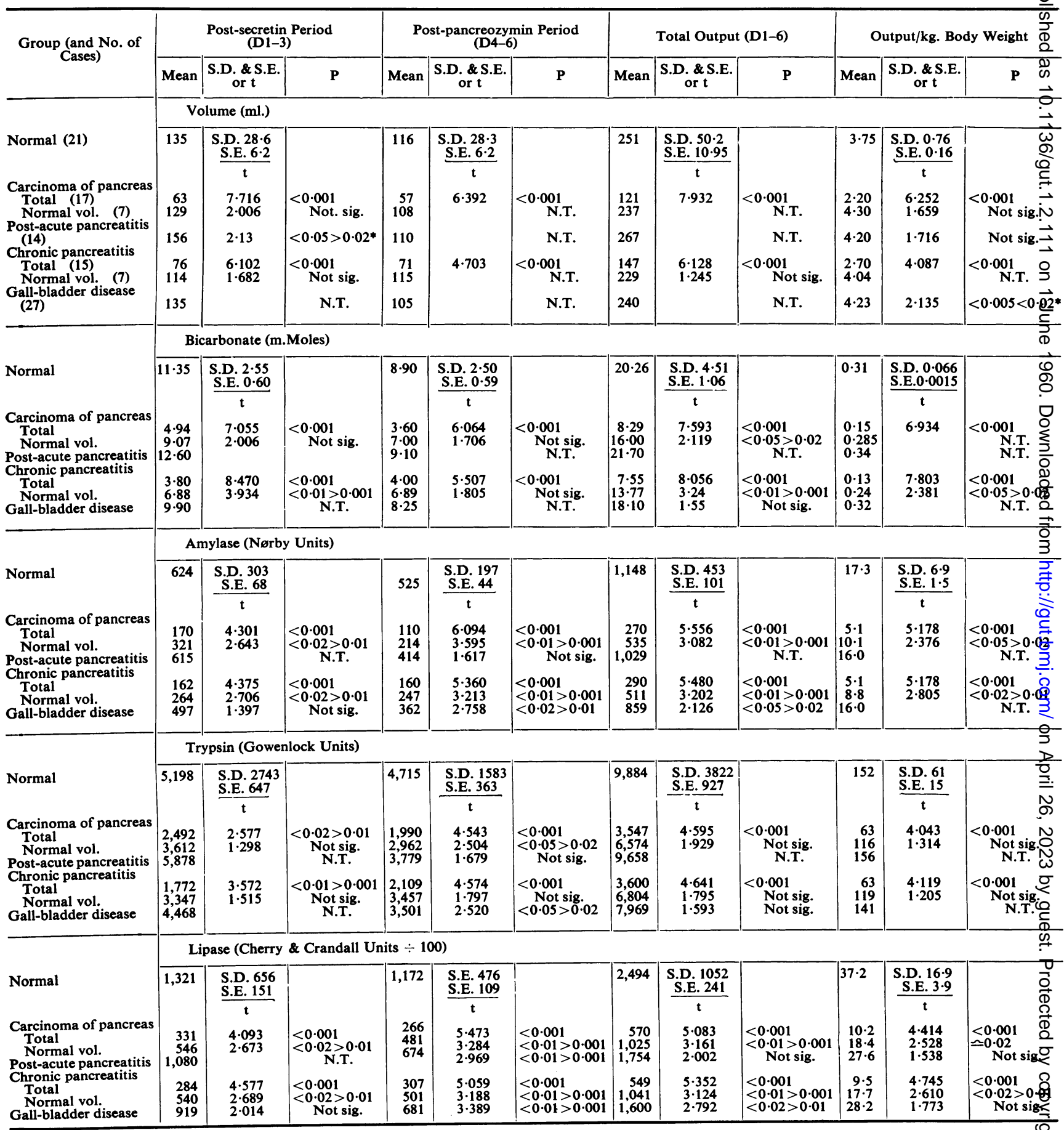

N.T. Significance not tested. Difference of means $<3$ S.E. of mean. *These values show a significant increase.

Not sig. $\quad P>0.05$. Difference not significant. 
cases have been calculated separately (Figs. 7 and 8). It was found that while the reduction of the bicarbonate output was just significant the total outputs of amylase and lipase were highly significantly reduced (Table III). The output of trypsin in the sample collected after pancreozymin (D4) was highly significantly reduced $(t=3 \cdot 670$; $0.01>P>0.001$ ).

One of these patients with cancer involving the head of the pancreas showed a response with a volume of $336 \mathrm{ml}$. in 60 minutes $(6 \cdot 22 \mathrm{ml} / \mathrm{kg}$. of body weight), 29.0 millimoles output of bicarbonate $(0.54 \mathrm{~m} . \mathrm{mole} / \mathrm{kg}$. of body weight) and enzyme outputs in excess of the normal mean. When this individual was excluded from the analysis, in the six remaining cases the reduction in bicarbonate output was highly significant $(t=3.024$; $0.01>P>0.001$, and the significance of the reduction of enzymes was increased.

CanCer of the Biliary Tract.-In four patients with cancer arising primarily in the bile ducts and obstructing the flow of bile, a normal pancreatic response to secretin and pancreozymin was obtained. Though the mean volume was slightly reduced due to bile duct obstruction, the mean bicarbonate concentration was high, and consequently the mean output of bicarbonate normal. The mean enzyme output was somewhat reduced.

PanCreatitis.-The 29 cases of pancreatitis available for statistical study have been divided into groups, one "post-acute pancreatitis", the other chronic pancreatitis. In the "post-acute" group were included $(a)$ those who had suffered from acute pancreatitis and were studied during the attack or up to nine months after recovery and $(b)$ those who had had recurring attacks of pancreatitis but showed no evidence of permanent pancreatic damage such as continuing diabetes, steatorrhoea, or calcification of the pancreas, and when followed for a period had remained well, in some instances after surgery of the biliary tract. The chronic pancreatitis group included those patients presenting with long-standing attacks, with evidence of permanent glandular damage such as diabetes, steatorrhoea, or calcification, and those in whom the surgeon noted a sufficient hardening in the gland to justify without doubt such a diagnosis. Such a division, though arbitrary, appears to be a valid functional classification.

"Post-acute Pancreatitis."-Associated gall bladder disease was found in eight of the 14 patients in this group. The mean results of the whole group show no significant deviation from normal apart from an increased volume in the post-secretin period. In one patient the concentration and output of enzymes was markedly reduced in spite of a normal volume and bicarbonate. In another patient who was inadvertently intubated during a mild attack of acute pancreatitis a raised volume $(6.46 \mathrm{ml} . / \mathrm{kg}$.) and high bicarbonate output were obtained $(0.50 \mathrm{~m} . \mathrm{mole} / \mathrm{kg}$. $)$ but the output of enzymes was normal.

Chronic Pancreatitis. - In the 15 cases of chronic pancreatitis evidence of more marked functional impairment is found, the volume and bicarbonate being reduced (Tables I and II). Since the common bile duct remains patent in most cases, the reduction in mean volume is not so great as in the cancer group but the bicarbonate output is even lower in spite of the contribution made by the liver and gall bladder bile to the total bicarbonate (Fig. 6). The mean outputs of amylase, trypsin, and lipase all showed a significant reduction $(0.01>P>0.001)$ in the postsecretin sample (D1) and a more marked reduction $(0.001>P)$ in the post-pancreozymin sample (D4), and the total output of enzymes was also markedly reduced $(0.001>P)$. A normal volume and enzyme response but elevated bicarbonate output was obtained in a patient in whom the chronic pancreatitis was localized to the head of the pancreas.

The individual total volumes fell within normal limits in seven of the 15 patients with chronic pancreatitis, and the mean output of bicarbonate and enzymes for this subgroup has been calculated separately (Fig. 7 and 8, Tables I and II). It was found that the mean output of bicarbonate was highly significantly reduced as were also the mean total outputs of amylase and lipase (Table III). The mean output of trypsin in the sample collected after pancreozymin D4 was significantly reduced $(t=2.348 ; 0.05>P>0.02)$.

Taking the cases of pancreatitis as a whole, it appears that normal function may be retained or rapidly regained after an attack of acute pancreatitis. Mild functional impairment may be demonstrated only by a poor enzyme output which is more obvious in post-pancreozymin values, and at a later stage bicarbonate output becomes affected and finally the volume reduced.

Gall Bladder Disease.-This is a heterogeneous group of 27 patients who had non-malignant disease affecting the gall bladder or bile ducts. In 11 patients cholecystectomy had been done before the intubation, without relief of symptoms. The feature of the whole group was a statistically significant increase in the mean volume of the duodenal contents, expressed per kilogram of body weight (Tables I and III). There is no change in the output of bicarbonate though the maximum mean bicarbonate concentration in D3 specimen is reduced to 
TABLE IV

NUMBER OF VALUES SIGNIFICANTLY DECREASED AND (IN BRACKETS) INCREASED IN INDIVIDUAL TESTS

\begin{tabular}{|c|c|c|c|c|c|c|c|c|c|}
\hline \multirow{2}{*}{ Diagnosis } & \multirow{2}{*}{$\begin{array}{c}\text { No. } \\
\text { of } \\
\text { Cases }\end{array}$} & \multicolumn{2}{|c|}{ Volume } & \multicolumn{3}{|c|}{ Bicarbonate } & \multirow{2}{*}{$\begin{array}{c}\text { Amylase } \\
\text { D4-6 }\end{array}$} & \multirow{2}{*}{$\begin{array}{c}\text { Trypsin } \\
\text { D4-6 }\end{array}$} & \multirow{2}{*}{$\frac{\text { Lipas }}{\text { D4-6 }}$} \\
\hline & & D1-6 & D1-3 & Maximum & D1-6 & D1-3 & & & \\
\hline $\begin{array}{l}\text { Cancer of pancreas } \\
\text { Pancreatitis: } \\
\text { (a) Post-acute } \\
\text { (b) Chronic } \\
\text { Gall-bladder disease } \\
\text { Cancer of bile ducts } \\
\text { Non-pancreatic steatorrhoea } \\
\text { Miscellaneous }\end{array}$ & $\begin{array}{r}17 \\
14 \\
15 \\
26 \\
4 \\
5 \\
3\end{array}$ & $\begin{array}{l}10 \\
1(3) \\
8 \\
2(4) \\
1 \\
0 \\
0\end{array}$ & $\begin{array}{l}11 \\
1(4) \\
8 \\
2(3) \\
0 \\
0 \\
0\end{array}$ & $\begin{array}{r}12 \\
0 \\
10 \\
2 \\
0 \\
0 \\
0\end{array}$ & $\begin{array}{l}11(1) \\
1(3) \\
9 \\
5(2) \\
0 \\
0 \\
0\end{array}$ & $\begin{array}{l}12(1) \\
0(3) \\
11(1) \\
4(2) \\
0 \\
0 \\
0\end{array}$ & $\begin{array}{r}15 \\
2 \\
9 \\
1 \\
0 \\
0 \\
0\end{array}$ & $\begin{array}{l}13 \\
1 \\
7 \\
4(1) \\
1 \\
0 \\
0\end{array}$ & $\begin{array}{r}13 \\
3 \\
8 \\
5 \\
1 \\
0 \\
0\end{array}$ \\
\hline
\end{tabular}

$8 \cdot 8$ m.mole $\%$, a significant difference $(t=3 \cdot 235$; $0.01>P>0.001)$. This increase in volume and lowered concentration of bicarbonate, present also in specimen D1 but most marked in specimen D3, is characteristic of gall bladder dysfunction and is due to the diluent effect of hepatic bile which the damaged gall bladder is unable to accept. There is some evidence of a reduction in the output of enzymes, particularly in the post-pancreozymin samples. In retrospect it seems likely that one if not two of the patients included in this group had impaired pancreatic function as well as primary biliary disease, but the exclusion of these cases does not substantially alter the mean results, or invalidate the conclusions drawn from them.

Non-PANCREATIC Steatorrhoea.-The mean volume and mean output of bicarbonate and enzymes did not differ significantly from the normal means in five patients in whom the steatorrhoea was due to defective intestinal absorption.

Miscellaneous Group.-Normal responses were obtained in two patients suffering from cirrhosis of the liver and in a third patient with essential hyperlipaemia.

\section{Significance of Individual Tests}

From the mean \pm 2 standard deviations of the values obtained in the normal group the normal limits for individual tests have been determined. There was no advantage in adjusting the data in terms of body weight, since the coefficient of variation for the normal volume and bicarbonate output and output of enzymes was not reduced by this manoeuvre. The output of enzyme obtained in response to pancreozymin (samples D4-6) was chosen as the best index of enzymatic activity of the pancreas since the variability of these samples in the normal group was less than either the post-secretin period or total output of enzyme, and since a comparison of the means of this value in pancreatic disease and in normal subjects had shown the maximal difference statistically (Table III).

The number of occasions in which abnormal values were obtained in the various pathological groups is recorded in Table IV. The abnormal results were in most cases reductions, but occasionally, as shown in the table, values were found which exceeded the upper normal limit. An indication of the value of this test in individual cases is that abnormally reduced values were found in 15 of the 17 cases of carcinoma and 12 of the 15 cases of chronic pancreatitis. In nine of the 14 cases in these two groups in which the volume of duodenal contents was within normal limits the value for bicarbonate or one or more enzymes or for both bicarbonate and enzymes was significantly reduced.

\section{Discussion}

It is a measure of the success of the experiments of Agren and Lagerlöf (1936) that their technique has been universally adopted with but few modifications. The method can be criticized in that duodenal intubation is irksome to an ill patient, difficult for the inexperienced technician to master, and necessitates readily accessible screening facilities. When duodenal intubation is practised occasionally or in ill patients, the gradual method of intubation is commended. Failure by this method is very rare and can be attributed to inadequate preparation of the patient by explanation, or to passing the tube too far in the early stages. Another fault which leads to failure to intubate the duodenum is the use of a tube which has been stored tightly curled.

When Crick et al. (1949) prepared samples of secretin and pancreozymin which were free from toxic and anaphylactic effects on animals an opportunity presented to examine the action of these preparations in man. The present experiments were designed primarily to elucidate the effect produced on the human pancreas by pancreozymin and further to determine the value of pancreozymin, a specific enzyme stimulant, in diagnosis. It seemed appropriate to test the effects of pancreozymin against a background of secretin-induced pancreatic secretion. The pattern of test designed by Ågren and Lagerlöf was therefore modified by injecting pancreozymin intravenously some 25 to 30 
minutes after the infusion of secretin, at a time when the stimulant action of secretin on the flow of pancreatic juice, still apparent, ensured quantitative recovery of the duodenal contents, and after the washing out of preformed enzyme from the pancreatic ducts by secretin had been completed. This design of the experiments has permitted in addition a comparison of the actions of secretin and pancreozymin.

The methods used to measure pancreatic enzyme concentration in duodenal contents have been chosen with care. For amylase, Lagerlöf's modification of the method of Nørby (Lagerlöf, 1942) has been successfully employed, and tryptic activity has been assessed by the method devised by Gowenlock (1953) for this study, in which denatured human serum protein is the substrate and the phenolic substances liberated by trypsin are measured colorimetrically. The method, analagous to Hunt's (1948) method for the estimation of pepsin, obviates the difficulties encountered in titrimetric methods for trypsin such as that described by Lagerlöf (1942) where the high concentration of bile pigments in the duodenal samples obtained in response to pancreozymin obscured the titration end-point. The method of Cherry and Crandall (1932) has in our hands proved the most convenient for the estimation of lipase. In subjects with a normal pancreas the output of enzymes measured by these methods shows considerable parallelism (Fig. 4).

Although all three enzymes-amylase, trypsin, and lipase-have been estimated in these experiments, in practice only one need be investigated, and amylase is the enzyme of choice. In only one of the 32 cancer and chronic pancreatitis patients was the post-pancreozymin amylase normal in the presence of an abnormal trypsin or lipase. In the groups of cancer and chronic pancreatitis cases with normal duodenal volumes the mean reductions of amylase and lipase, expressed as percentages of the normal outputs, were about the same, but the mean reduction in trypsin was considerably less, although with the small number of cases involved this apparent "dissociation of enzymes" is not statistically significant. Lagerlöf (1939) also noted that trypsin activity in duodenal contents might be normal when the amylase output was depressed after acute pancreatitis, and somewhat similar results have been reported by Diamond and Siegel (1941).

Before accepting this indication of a dissociation of pancreatic enzymes in disease, it would be essential to prove that proteolytic activity of the duodenal contents is wholly due to pancreatic trypsin and not in part the result of proteolytic enzymes in intestinal secretion, which would not be affected in pancreatic disease. On this point we have no evidence. The practical conclusion, however, is that in the diagnostic use of the secretinpancreozymin test trypsin and lipase estimations may be omitted. This is of advantage not only in saving laboratory time but because these enzymes are more labile than amylase and require careful preservation during and after the period of collection by cooling in the presence of glycerol.

In normal man, following secretin, the volume of duodenal contents rises. A second rise in volume follows pancreozymin, largely if not entirely due to the presence of cholecystokinin in preparations of pancreozymin. So far as is known, cholecystokinetic activity usually accompanies pancreozymin activity on purification (Harper, 1959; Jorpes and Mutt, 1959) and there is only one report of the two having been separated (Greengard and Ivy, 1945). However, this permits a simultaneous assessment of gall bladder and pancreatic function in man when the secretin-pancreozymin test is used (Duncan et al., 1952; Burton et al., 1960a.

In pancreatic disease functional impairment of the gland has been most often demonstrated in patients with cancer of the pancreas and chronic pancreatitis. In cancer, where the obstructive element is the more marked, the characteristic feature in response to secretin is a reduced volume of the duodenal contents whereas in chronic pancreatitis where destructive features dominate, a reduced output of bicarbonate is more prominent. The post-secretin (D1-3) output of bicarbonate was significantly low in only one of the six patients with a normal post-secretin volume in the cancer group compared with three of seven such patients in the chronic pancreatitis group. This distinction between the two groups has been stressed by Dreiling (1951, 1953) and reaffirmed by Dreiling and Janowitz (1956), but too much importance should not be made of the distinction when assessing the pathology of an individual case since duct obstruction from inflammation and stones is sometimes found in chronic pancreatitis, and accompanying pancreatitis and atrophy are not uncommonly encountered in primary cancer of the pancreas. Hence in either disease a reduction of volume or of bicarbonate in response to secretin may predominate.

The consensus of opinion is that enzyme estimations add little to the diagnostic value in the secretin test (Dornberger et al., 1948), and recently Sun and Shay (1957) omitted them when using the test. Parasympathomimetic agents such as mecholyl (Comfort and Osterberg, 1940) and insulin (Diamond and Siegel, 1940; Friedman and Snape, 1950), which have been used in conjunction with 
secretin to stimulate enzyme production, have the disadvantage of producing many side effects. It was therefore of particular interest to determine whether by the addition of the specific enzyme stimulant pancreozymin alterations in enzyme output in pancreatic disease could be detected, which were not apparent in the response to secretin alone. The significance of the differences between the mean outputs of enzymes in the normal group and in the groups of patients with chronic pancreatitis and cancer of the pancreas, in whom the volume of duodenal contents was normal, was tested statistically. The outputs after secretin (D1-3) and after pancreozymin (D4-6) were examined separately, and for all three enzymes the " $t$ " values were greater after pancreozymin than after secretin. This result, which follows from the greater scatter of individual results in the immediate post-secretin (D1) sample than in the post-pancreozymin (D4) sample, should make abnormalities in enzyme output more easily detectable in the postpancreozymin period. This is so in fact, and we have found in cancer of the pancreas that diminution in post-pancreozymin output of enzyme is a more sensitive index of impaired pancreatic function than lowered volume of bicarbonate.

Dreiling and Hollander (1950) found that the scatter of enzyme results after secretin was reduced if the results were related to body weight, and suggested that in earlier investigations a variable contamination of secretin by pancreozymin might have been one factor in producing the scatter. The secretin used in our experiments was free of pancreozymin, and there was no reduction in scatter when the results were expressed in terms of body weight. Marks and Tompsett (1958) have reported observations in which pancreozymin was given 60 minutes after secretin, but they pooled all their samples and estimated an 80-minute amylase concentration. In our experiments this corresponds most closely to the total (D1-6) amylase output which we have found a less sensitive index of abnormality than the post-pancreozymin (D4-6) output.

When the individual results in the cancer of the pancreas and chronic pancreatic groups are considered, and the enzyme response to pancreozymin compared with the bicarbonate response to secretin a difference between the cancer group and chronic pancreatitis group emerges. The post-pancreozymin (D4-6) output of amylase was significantly decreased in 15 of the 17 patients in the cancer group, whereas the post-secretin (D1-3) output of bicarbonate was low in 12. The post-pancreozymin output of amylase was low in only nine of the 15 patients in the group with chronic pancreatitis whereas the post-secretin output of bicarbonate was reduced in 11 patients (Table IV). From this the output of enzyme in response to pancreozymin appears to be more valuable in the diagnosis of cancer of the pancreas than of chronic pancreatitis. The serum enzymes evoked in response to secretin and pancreozymin were significantly elevated in one of the two cancer cases and four of the six cases of chronic pancreatitis in which the post-pancreozymin duodenal amylase was normal. A combined study of duodenal contents and serum enzymes, as suggested by Sun and Shay (1957), does therefore lead to a high proportion of significantly positive tests, 29 out of 32 , in these two groups.

After acute pancreatitis evidence of impaired pancreatic function is not often met since severely ill patients are not tested and in milder attacks rapid restoration of function ensues. As Dreiling (1953) has indicated, use may be made of this as a prognostic test. If pancreatic function is impaired more permanent structural damage associated with chronic pancreatitis is likely to persist after an acute attack. Since this may lead to further attacks the test can be used to indicate the necessity for further definitive treatment.

In gall bladder disease a significant rise in the volume of duodenal output following secretin has been recognized (Ågren and Lagerlöf, 1937). This increase, due to the increased flow of hepatic bile when gall bladder function is impaired, we have found to be associated with a mean decrease in concentration of bicarbonate in post-secretin samples (D1 and D3) though the output of bicarbonate in these samples is normal. Concentration values of bicarbonate should not therefore be used to indicate pancreatic dysfunction in the presence of gall bladder disease. The few instances of lowered post-pancreozymin enzyme found in gall bladder disease have been attributed to unrecognized pancreatitis.

The secretin-pancreozymin test can distinguish in obstructive jaundice between primary cancer of the bile ducts (in which pancreatic function is normal) and primary cancer of the pancreas. Again it can with certainty distinguish between steatorrhoea associated with pancreatic insufficiency and nonpancreatic steatorrhoea. The presence of blood in duodenal samples has indicated involvement of the duodenum by growth.

Though pancreatic disease is manifest when diminished volume and output of bicarbonate and enzymes are present, mention must be made of certain elevated values which have been encountered. In four of the five patients tested within 14 days of an acute attack of pancreatitis elevated values for post-secretin output of bicarbonate or output $/ \mathrm{kg}$. 
of body weight were recorded. The post-secretin volume of duodenal contents was raised in three of these patients, in two of whom gall stones were present, but in the third gall bladder function was normal at the time of the test. A raised bicarbonate output was encountered also in two patients with gall bladder disease (one of whom had associated cholangitis), in a patient, already recorded, with an early cancer of the head of the pancreas who had a raised output of pancreatic juice but normal gall bladder function, and in another with chronic pancreatitis localized to the head of the pancreas. It is difficult to attribute this finding to gall bladder disease solely since gall bladder function was normal in at least three of these patients, and it can only be assumed that at an early state of pancreatic injury an increased flow of pancreatic juice with normal bicarbonate concentration (but high bicarbonate output) may result from stimulation with secretin. The post-pancreozymin output of enzymes was not increased in any of these cases. A similar abnormal secretory response was reported by Gross, Comfort, Wollaeger, and Power (1950) in parenchymatous hepatic disease. Liver damage, however, cannot explain the findings in our cases. Lake (1947) and Andrus, Lord, and Lake (1942) have reported a patient with cancer of the pancreas with functional overactivity of the pancreas. None of these patients had severe attacks of pancreatitis and the possibility remains that in mild pancreatitis the pancreas may excrete excessive fluid of normal bicarbonate concentration in response to secretin in the acute and early recovery phase.

Professor Walter Schlapp, of the Department of Physiology, University of Manchester, made available the laboratory and workshop facilities of his department to us throughout this study. We acknowledge his help gratefully and the help of Dr. P. R. Duncan and Miss Josephine Smith who were associated with the early stages of this work, as was Mrs. J. F. Patrick who for a time undertook bicarbonate estimations on our behalf. We are grateful to Mr. D. J. Newell, Lecturer in Statistics, King's College, Newcastle upon Tyne, for helpful advice on the statistical presentation of the results, and to Dr. R. G. Ollerenshaw, of the Department of Medical Illustration, Manchester Royal Infirmary, for the final graphic form in which they appear. We also wish to thank Miss Ann C. Heckels and Mrs. Hilda Hodkinson for their invaluable assistance in the preparation of the tables and manuscript. Finally, we are indebted to the Research Grants Committee of the Board of Governors, the United Manchester Hospitals, who contributed a generous grant to finance this work, and to the Boots Pure Drug Company, Limited of Nottingham, for liberal supplies of both secretin and pancreozymin.

\section{REFERENCES}

Ågren, G., and Lagerlöf, H. (1936). The pancreatic secretion in man after intravenous administration of secretin. Acta med. scand. 90, 1.

92 (1937). The biliary response in the secretin test. Ibid.,

Andrus, W. de W., Lord, J. W., and Lake, M. (1942). Tests of hepatic and pancreatic function in the differential diagnosis and preparation of patients with lesions of the biliary tract. Ann. Surg., 115, 1015.

Bayliss, W. M. M. and Starling, E. H. (1902). The mechanism of pancreatic secretion. J. Physiol. (Lond.), 28, 325.

Bolgert, M. (1935). Lésions du pancrérs et troubles fonctionels pancréatiques: Diagnostic en clinique par l'épreuve à la sécrétine purifiée. Masson, Paris.

Burton, P., Harper, A. A., Howat, H. T., Scott, J. E., and Varley, H. (1960a). The use of cholecystokinin to test gall bladder function in man. Gut. To be published.

- Hammond, Elizabeth M., Harper, A. A., Howat, H. T. Scott, J. E., and Varley, H. (1960b). Serum amylase and serum lipase levels in man after administration of secretin and pancreozymin Ibid., 1, 125 .

Cherry, I. S., and Crandali, L. A. (1932). The specificity of pancreatic lipase: its appearance in the blood after rancreatic injury. Amer. J. Physiol., 100, 266.

Chiray, M., Jeandel, A., and Salmon, A. (1930). L'exploration clinique du pancréas et l'injection intraveineuse de sécrétine purifiée. Presse méd., 38, 977.

_, Salmon, A. R., and Mercier, A. (1926). Action de la secretine purifiée sur la secretion externe du pancreas de l'homme. Bull. Soc. méd. Hôp. Paris, 3 ser., 50, 1417.

Comfort, M. W., and Osterberg, A. E. (1940). Pancreatic secretion in man after stimulation with secretin and acetylbetamethycholine chloride. Arch. intern. Med., 66, 688.

Crick, Joan, Harper, A. A., and Raper, H. S. (1949). On the preparation of secretin and pancreozymin. J. Physiol. (Lond.), 110, 367.

Diamond, J. S., and Siegel, S. A. (1940). The secretin test in the diagnosis of pancreatic diseases with a report of one hundred and thirty tests. Amer. J. dig. Dis., 7, 435.

- (1941). The clinical application of secretin in the study of pancreatic function. N.Y. St. J. Med., 41, 869 .

, Gall, M. B., and Karlen, S. (1939). The use of secretin as a clinical test of pancreatic function. Amer. J. dig. Dis., 6, 366 .

Dornberger, G. R., Comfort, M. W., Wollaeger, E. E., and Power, Marschelle H. (1948). Pancreatic function as measured by analysis of duodenal contents before and after stimulation with secretin. Gastroenterology, 11, 701 .

Dreiling, D. A. (1950). Studies of pancreatic function. III. The use of the secretin test in the diagnosis of patients with the post-cholecystectomy syndrome. Ibid., 16, 162.

post-cholecystectomy syndrome. Ibid., 16, 162.
(1951). Studies in pancreatic function. IV. The use of the secretin test in pancreatic runction.

pancreas. Ibid., 18, 184.
(1953). Studies in pancreatic function. V. The use of the secretin test in the diagnosis of pancreatitis and in the demonstration of pancreatic insufficiencies in gastrointestinal disorders. Ibid., 24, 540.

(1955). The technique of the secretin test: normal ranges. J. Mt Sinai Hosp., 21, 363.

-, and Hollander, F. (1948). Studies in pancreatic function. I. Preliminary series of clinical studies with the secretin test. Gastroenterology, 11, 714

Gastroenterology, 11, 714 .
(1950). Studies in pancreatic function. II. A statistical study of pancreatic secretin following secretin in patients without pancreatic disease. Ibid., 15, 620 .

and Janowitz, H. D. (1956). Exocrine pancreatic secretion. Effects of pancreatic disease. Amer. J. Med., 21, 98. Ecc57). The labeaser diagnosis of pancreatic disease: secretin test. Amer. J. Gastroent., 28, 268.

Duncan, P. R. Evans, D. G., Harper, A. A., Howat, H. T., Oleesky, S., Scott, J. E., and Varley, H. (1953). The use of the cholecystokinetic agent in preparations of pancreozymin to study gall bladder function in man. J. Physiol. (Lond.), 121, 19P.

-, Harper, A. A., Howat, H. T., Oleesky, S., and Varley, H. (1950). The effects of pancreozymin on human subjects. Ibid., 111, 63P.

(1952). Tests of gall-bladder function in man. The use of preparations containing cholecystokinin. in man. The use of preparations

Euler, U. S. von, and Gaddum, J. H. (1931). An unidentified depressor substance in certain tissue extracts. J. Physiol. (Lond.), 72,74 .

Friedman, M. H. F., and Snape, W. J. (1950). Dissociation of secretion of pancreatic enzymes and bicarbonate in patients with chronic pancreatitis. Gastroenterology, 15, 296

Gowenlock, A. H. (1953). The estimation of tryptic activity in duodenal contents. Biochem. J., 53, 274.

Greengard, $H$., and Ivy, A. C. (1945). The preparation and biological assay of a pancreozymin concentrate. Fed. Proc., 4, 26. 
Gross, J. B., Comfort, M. W., Wollaeger, E. E., and Power, Marschelle H. (1950). External pancreatic function in primary parenchymatous hepatic disease as measured by analysis of duodenal contents before and after stimulation with secretin Gastroenterology, 16, 151.

Hareer, A. A. (1959). Physiologic factors regulating pancreatic secretion. Ibid., 36, 386 .

-, and Raper, H. S. (1943). Pancreozymin, a stimulant of the secretion of pancreatic enzymes in extracts of the small intestine. J. Physiol. (Lond.), 102, 115 .

Howat, H. T. (1952). In Modern Trends in Gastroenterology, p. 766 Ed. F. Avery Jones. Butterworth, London.

Hultman. E. H. (1955a). The relation between cholecystokinin and substance P. Acta chem. scand., 9, 1042.

- (1955b). A method for the standardization of cholecystokinin in vitro. Acta physiol. scand., 33, 291.

Hunt, J. N. (1948). A method for estimating peptic activity in gastric contents. Biochem. J., 42, 104.

Ivy, A. C., and Oldberg, E. (1928). A hormone mechanism for gallbladder contraction and evacuation. Amer. J. Physiol., 86, 599.

Jorpes, E., and Mutt, V. (1956). Sekretin, pankreozymin och cholecystokinin. Nord. Med., 56, 1511.

- - (1959). Secretin, pancreozymin and cholecystokinin. Their preparation and properties. Gastroenterology, 36, 377.

Lagerlöf, H. (1939). The secretin test of pancreatic function. Quart. J. Med. n.s. $8,115$.

Lagerlöf, H. O. (1942). Pancreatic function and pancreatic disease studied by means of secretin. Acta med. scand., Suppl., 128.
Lake, M. (1947). Diagnostic value of the secretin test. Amer. J. Med., 3, 18.

Lim, R. K.'S., Matheson, A. R., snd Schlapp, W. (1923). An improved method for investigating the secretory function of the stomach and duodenum in the human subject. Quart. J. exp. Physiol., 13, 333.

Marks, I. N., and Tompsett, S. L. (1958). The diagnosis of pancreatic disease. Quart. J. Med., n.s., $27,431$.

Pearson, E. S., and Hartley, H. O. (1954). Biometrika Tables for Statisticians, Vol. 1, p. 19. University Press, Cambridge.

Peters, J. P., and van Slyke, D. D. (1932). Quantitative clinical Chemistry, Vol. 2. Williams and Wilkins, Baltimore.

Pollard, H. M., Miller, L., and Brewer, W. A. (1942). A clinical study of the secretin test. Amer. J. dig. Dis. 9, 68 .

Pratt, Judy of the secretin test. Amer. and Roster, A. E (1940). The secretin test of pancreatic function. Trans. Ass. Amer. Phycns, 55, 154.

Sun, D. C. H., and Shay, H. (1957). Value of combined study of serum enzymes and duodenal contents after secretin in the diagnosis of diseases of the pancreas. Gastroenterology, 32, 212 .

Voegtlin, W. L., Greengard, M., and Ivy, A. C. (1934). The response of the canine and human pancreas to secretin. Amer. J. Physiol., 110, 198.

Voet, R. (1943). Etude clinique et radiologique des syndromes pancréatiques chroniques. Vermaut, Courtrai.

Wenger, J., and Raskin, H. F. (1958). The diagnosis of cancer of the pancreas, biliary tract and duodenum by combined cytologic and secretory methods. II. The Secretin Test. Gastroenterology, 34, 1009-1017. 